\title{
Correction to: Cooperation by ant queens during colony-founding perpetuates alternative forms of social organization
}

\author{
Pierre Blacher $^{1}\left[\right.$ ] Ornela De Gasperin $^{1}\left(\mathbb{D} \cdot\right.$ Michel Chapuisat $^{1}(\mathbb{C}$
}

Published online: 31 December 2021

(CThe Author(s) 2021

\section{Correction to: Behavioral Ecology and Sociobiology https://doi.org/10.1007/s00265-021-03105-1}

The article "Cooperation by ant queens during colony-founding perpetuates alternative forms of social organization", written by Pierre Blacher, Ornela De Gasperin and Michel Chapuisat, was originally published electronically without open access. With the author(s)' decision to opt for Open Choice the copyright of the article changed on 28 December 2021 to (CThe Author(s) 2021 and the article is forthwith distributed under a Creative Commons Attribution 4.0 International License, which permits use, sharing, adaptation, distribution and reproduction in any medium or format, as long as you give appropriate credit to the original author(s) and the source, provide a link to the Creative Commons licence, and indicate if changes were made. The images or other third party material in this article are included in the article's Creative Commons licence, unless indicated otherwise in a credit line to the material. If material is not included in the article's Creative Commons licence and your intended use is not permitted by statutory regulation or exceeds the permitted use, you will need to obtain permission directly from the

The original article can be found online at https://doi.org/10.1007/ s00265-021-03105-1.

Pierre Blacher

pierre.blacher@unil.ch

1 Department of Ecology and Evolution, University

of Lausanne, Lausanne, Switzerland copyright holder. To view a copy of this licence, visit http:// creativecommons.org/licenses/by/4.0.

The original article has been corrected.

Open Access This article is licensed under a Creative Commons Attribution 4.0 International License, which permits use, sharing, adaptation, distribution and reproduction in any medium or format, as long as you give appropriate credit to the original author(s) and the source, provide a link to the Creative Commons licence, and indicate if changes were made. The images or other third party material in this article are included in the article's Creative Commons licence, unless indicated otherwise in a credit line to the material. If material is not included in the article's Creative Commons licence and your intended use is not permitted by statutory regulation or exceeds the permitted use, you will need to obtain permission directly from the copyright holder. To view a copy of this licence, visit http://creativecommons.org/licenses/by/4.0/.

Publisher's note Springer Nature remains neutral with regard to jurisdictional claims in published maps and institutional affiliations. 